\title{
$U$ and Th isotope constraints on the duration of Heinrich events H0-H4 in the southeastern Labrador Sea
}

\author{
C. C. Veiga-Pires ${ }^{1}$ and C. Hillaire-Marcel
}

Centre de Recherche en Géochimie et en géochronologie Isotopique (GEOTOP), Université du Québec à Montréal Montréal, Québec, Canada

\begin{abstract}
The duration and sequence of events recorded in Heinrich layers at sites near the Hudson Strait source area for ice-rafted material are still poorly constrained, notably because of the limit and uncertainties of the ${ }^{14} \mathrm{C}$ chronology. Here we use high-resolution ${ }^{230}$ Th-excess measurements, in a $6 \mathrm{~m}$ sequence raised from Orphan Knoll (southern Labrador Sea), to constrain the duration of the deposition of the five most recent Heinrich $(\mathrm{H})$ layers. On the basis of maximum/minimum estimates for the mean glacial ${ }^{230} \mathrm{Th}$-excess flux at the studied site a minimum/maximum duration of $1.0 / 0.6,1.4 / 0.8,1.3 / 0.8,1.5 / 0.9$, and $2.1 / 1.3 \mathrm{kyr}$ is obtained for $\mathrm{HO}$ ( Younger Dryas), H1, H2, H3, and H4, respectively. Thorium-230-excess inventories and other sedimentological features indicate a reduced but still significant lateral sedimentary supply by the Western Boundary Undercurrent during the glacial interval. $U$ and Th series systematics also provide insights into source rocks of $\mathrm{H}$ layer sediments (i.e., into distal Irminger Basin/local Labrador Sea supplies).
\end{abstract}

\section{Introduction}

Deep-sea cores from the Labrador Sea provide highresolution records of Heinrich layers [cf Heinrich, 1988; Bond et al., 1992; Bond and Lotti, 1995] and other fast deposited units (FDUs) deposited during the last glaciation [Stoner et al., 1996]. In the North Atlantic, FDUs include abundant ice-rafted debris (IRD) from various origins [Lehman et al., 1991; Bond et al., 1992; Grousset et al., 1993; Broecker, 1994]. In the deep Labrador Sea, notably, most of these layers include high detrital carbonate contents [Andrews and Tedesco, 1992; Hillaire-Marcel et al., 1994a; Stoner et al., 1996], notably those correlative with the North Atlantic Heinrich layers HO ( Younger Dryas [Andrews et al., 1995]), H1, H2, H3, and H4 [Andrews et al., 1994; HillaireMarcel et al., 1994a; Bond and Lotti, 1995; Stoner et al., 1996]. In these FDUs the IRD peaks linked to iceberg production episodes show a slight offset with the detrital carbonate pulses that are triggered by ice surges and/or subglacial meltwater outflows in the Hudson Strait area [Andrews and Tedesco, 1992; Hillaire-Marcel et al., 1995; Hesse et al., 19971. Most FDUs from the Labrador Sea also show a peak of IRD toward the top of the unit which roughly matches a peak of light $\delta^{18} \mathrm{O}$ values in Neogloboquadrina pachyderma (left coiling, $\mathrm{Npl}$ ) shells, likely responding to major dilution of surface waters by iceberg melting [Bilodeau et al., 1997]. This late stage of Heinrich events probably correlates directly to the negative isotopic shift observed in Greenland ice cores during Dansgaard-Oeschger climate oscillations [Dansgaard et al., 1982]. However, an

\footnotetext{
1 Now at Universidade do Algarve, Faro, Portugal.

Copyright 1999 by the American Geophysical Union

Paper number 1998PA900003.

0883-8305/99/1998PA900003\$12.00
}

unequivocal explanation for this link requires a better chronological control for the sequence of events involved in a given oscillation. From this viewpoint the determination of the total duration of Heinrich events can help to constrain better the triggering mechanisms involved as well as to assess better the paleoceanographic and paleoclimatic implications of their occurrence. As a matter of fact, in their binge and purge model, Alley and MacAyeal [1994] proposed several possible schemes which are a function of the duration of Heinrich events.

Radiocarbon dating do not necessarily provide precise age estimates for the duration of Heinrich events. First, the analytical uncertainty for low ${ }^{14} \mathrm{C}$ contents (e.g., $\mathrm{H} 3$ and older events) results in large age uncertainties, the order of magnitude of which is that of the event duration itself $\left(\sim 10^{3}\right.$ years [Bond et al., 1992]). Second, rapid changes in the ${ }^{14} \mathrm{C}$ activity of the atmospheric $\mathrm{CO}_{2}$ during such events may have occurred, resulting in a ${ }^{\text {"14 }} \mathrm{C}$ plateau effect" such as that illustrated by Ammann and Lotter [1989] and Broecker [1994] for the Younger Dryas-H0 event, and thus a possible bias when interpolating ages. Third, changes in the oceanic circulation during the $H$ events [Broecker, 1994] may have induced rapid shifts in the apparent ${ }^{14} \mathrm{C}$ ages of the water masses occupied by the $\mathrm{Npl}$ assemblages, notably, in many cases, the only planktonic species available for ${ }^{14} \mathrm{C}$ measurements. On the basis of a work by Bard [1988] it seems that such an effect prevailed during the HO-Younger Dryas event, shifting the apparent age of the North Atlantic subsurface water from 800 to 400 years.

We will use here another method, based on ${ }^{230}$ Th excesses in sediments from a high-resolution record of the SE Labrador Sea, as a means of constraining the duration of the five younger Heinrich events (H0-H4) Francois and Bacon [1994] already made attempts at using ${ }^{230} \mathrm{Th}$ excesses in a NE Atlantic core to derive first-order estimates for the duration of $\mathrm{H} 1$ and $\mathrm{H} 2$. They calculated a duration of $\sim 600$ and 800 years, respectively. On the basis of similar approaches, Thomson et al. [1995] 
calculated depositional times of $\sim 2.1,1.1$, and $>0.7 \mathrm{kyr}$ for $\mathrm{H1}$, $\mathrm{H} 2$, and $\mathrm{H} 4$, respectively. Such time discrepancies might be explained by the fact that the parameters controlling ${ }^{230} \mathrm{Th}$ fluxes, particularly along continental margins, are still poorly constrained. The present study may therefore provide additional information on possible geographical differences in the duration of $\mathrm{H}$ events. Furthermore, the location of our study site, which, compared with the previous works, is closer to the major sediment source area for the $H$ layers under examination [Andrews et al., 1995], presents the advantage of showing a more exhaustive record of the sequence of sedimentological events involved in the deposition of each of these layers, thus better grounds for estimating their total duration.

Thorium-230 fluxes derived from deep sea core studies are currently interpreted as the sum of a vertical component, linked to the decay of the parent ${ }^{234} \mathrm{U}$ in the overlying water column, and of a lateral component (see the focusing factor of Suman and Bacon [1989], and the nepheloid layer transport of Scholten et al. [1990]). Recent studies also indicate that ${ }^{230} \mathrm{Th}_{\text {exceses }}$ may be influenced by the mineralogical and geochemical properties of the organomineral scavengers [Jannasch et al., 1988; Honeyman and Santschi, 1992; Niven et al., 1995]. Furthermore, the dimension of the scavenging particles is as critical a factor as their sorting by currents, and therefore their travel times and trajectories will vary accordingly. Advection of ${ }^{230}$ Th carriers in the water column and transport in the nepheloid layer may likely involve distinct particles. Therefore ${ }^{230} \mathrm{Th}_{\text {excesses }}$ seem to depend on a combination of factors, namely, the nature, trajectories, and rates of sedimentary supply and of water mass ventilation [Anderson et al., 1983; Scholten et al., 1990; Moran and Moore, 1992; Yu et al., 1996; Moran et al., 1997]. For given settings and time intervals, as in the present study, it may be possible to determine some of these parameters from complementary studies and to put constraints on sediment accumulation rates based on ${ }^{230} \mathrm{Th}_{\text {excessea }}$

The core used in the present study was raised from the Orphan Knoll area on the Labrador Rise (Figure 1) near the Northwest Atlantic Mid Ocean Channel (NAMOC), i.e., a major feature with respect to sedimentary fluxes in the northwestern North Atlantic [Chough and Hesse, 1976]. Therefore it may then have occasionally received turbiditic material spreaded along this channel [Hesse et al., 1997]. Sedimentary supply at the site is also influenced by the Western Boundary Undercurrent (WBUC) whose highvelocity core is located slightly upslope [McCartney, 1992]. About $60 \%$ of the carbonate-free clay fraction in the Holocene section of the core is composed of smectites originating from the Irminger Sea and the Reykjanes Ridge areas (Figure 1) [Fagel et al., 1996]. Other clay minerals include illites and chlorites which reflect local terrigenous fluxes [Fagel et al., 1996]. Adding to this terrigenous component, authigenic carbonates linked to coccolithophorids production [HillaireMarcel et al., 1994b] represent almost $40 \%$ of the Holocene sediment. Their grain size averages $4 \mu \mathrm{m}$ [Veiga-Pires, 1998]. It is thus likely that these carbonates may have also been transported from remote production areas, possibly as far as the Irminger Basin, to the study site.

On the basis of sedimentological and clay mineral studies of the late Quaternary section of 91-045-094-P, Fagel et al.
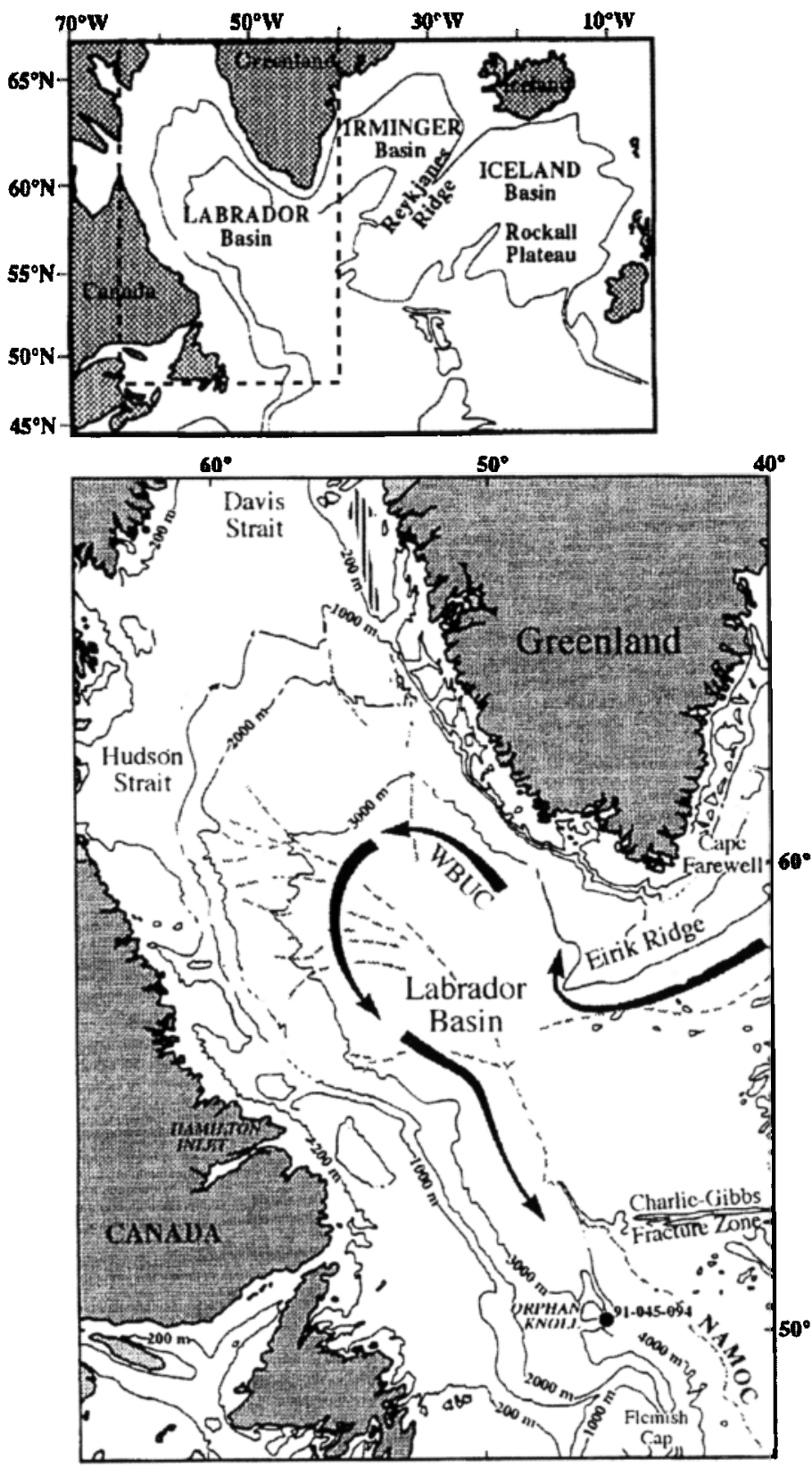

Figure 1. Location map of core HU-91-045-094 $\left(50^{\circ} \mathrm{N}, 45^{\circ} \mathrm{W}\right)$ raised from the Labrador Rise east of Orphan Knoll.

[1997] concluded that a relatively steady but weak WBUC outflow prevailed during isotopic stages 2 and 3 in contrast to the high outflow of the late glacial and postglacial times. Relatively steady sedimentary fluxes at site 91-045-094 are assumed in this study, with the exception of the Heinrich events themselves, on the basis of the available age measurements downcore [Hillaire-Marcel et al., 1994a; Stoner et al., 1998]. This strengthens the use of ${ }^{230} \mathrm{Th}$ excesses as an appropriate recorder of sedimentation rate changes during these events.

\section{Material and Methods}

The study core 91-045-094-P (henceforth P-094; $50^{\circ} 12.26{ }^{\prime} \mathrm{N}$; $45^{\circ} 41.14^{\prime} \mathrm{W}$; water depth $3448 \mathrm{~m}$ ) was raised 
during Canadian Survey Ship (CSS)-Hudson cruise 91-045. The core primarily consists of hemipelagic muds with interlayered sands, gravel, and silty clays. It spans isotopic stages $5 \mathrm{a}$ to 1 as shown by detailed sedimentological, mineralogical, isotopic, and rock-magnetic studies [HillaireMarcel et al., 1994a, b; Stoner et al., 1996; Fagel et al., 1997]. Here we will examine the upper $620 \mathrm{~cm}$ section which contains layers $\mathrm{H} 0-\mathrm{H} 4$. Analyses were made at $1 \mathrm{~cm}$ intervals from 173 to $184 \mathrm{~cm}$ and from 228 to $248 \mathrm{~cm}$ (i.e., throughout the sections corresponding to $\mathrm{H}$ layers 0 and 1 [Stoner et al., 1996]). They were performed at $2 \mathrm{~cm}$ intervals for layers 2,3 , and 4 (i.e., from 365 to $381 \mathrm{~cm}, 463$ to $475 \mathrm{~cm}$, and 561 to 590 $\mathrm{cm}$, respectively). The layer boundaries were first determined on a visual criteria, i.e., on the basis of the light color of the carbonate-rich oxidized $\mathrm{H}$ layers which contrasts with the dark color of the reduced hemipelagic layers [see also Stoner et al., 1996]. The interlayered and overlying sediments were analyzed at $5 \mathrm{~cm}$ intervals when possible (i.e., when enough material was left from previous studies) and otherwise were analyzed at $10 \mathrm{~cm}$ intervals.

Organic and inorganic carbon contents were measured using an elemental analyzer (Carlo-Erba ${ }^{\mathrm{TM}}$ ). The inorganic carbon content is expressed in equivalent $\mathrm{CaCO}_{3}$ (dry weight percent). The average overall analytical uncertainty of both inorganic and organic carbon (Corg) is $3 \%( \pm 1 \sigma)$.

The oxygen isotope stratigraphy was established on $N$. pachyderma (left coiling $\mathrm{Npl}$ ) assemblages using an Isocarb $^{\mathrm{TM}}$ preparation device on line with a triple-collector VG-Prism instrument. Results are expressed against Peedee belemnite (PDB) after applying the conventional corrections [Craig, 1957]. Overall analytical uncertainties determined from replicate measurements of standard carbonate were better than $\pm 0.05 \%$ ( $1 \sigma$ ). Radiocarbon stratigraphy for $0.25 \mathrm{ka}$ is based on accelerator mass spectrometry (AMS) ${ }^{14} \mathrm{C}$ measurements on monospecific (Npl) assemblages made at the IsoTrace laboratory of the University of Toronto. Results were corrected by 400 years to account for the apparent age of the North Atlantic Ocean surface waters [Bard, 1988] and calibrated to sideral years using the Calib3 program of Stuiver and Reimer [1993]. For the time interval greater than $25 \mathrm{ka}$ and because of possible serious bias in the ${ }^{14} \mathrm{C}$ chronology beyond $30 \mathrm{ka}$ [Stoner et al., 1998], we used the chronological linkage of core P-094 to the SPECMAP scale of Martinson et al. [1987] proposed by Stoner et al. [1998] on the basis of magnetic paleointensity data.

$\mathrm{U}$ and $\mathrm{Th}$ series measurements were made by alpha spectrometry with an EGG-Ortec counting system. Chemical extraction from bulk sediment was done according to conventional techniques [Lally, 1992] using a ${ }^{228} \mathrm{Th}-{ }^{232} \mathrm{U}$ double spike. Counting statistics yielded a standard deviation better than $\pm 3 \%$ for all isotopes (see Veiga-Pires [1998] for more details). U-Th measurement data are expressed in activities (dpm $\mathrm{g}^{-1}$ of dry weight sediment) and in activity ratios. Thorium-230 excesses (henceforth ${ }^{230} \mathrm{Th}_{\mathrm{xs}}$ ) are considered to represent the fraction of ${ }^{230} \mathrm{Th}$ scavenged from the water column by organomineral matter. In practice it is assimilated to the unsupported ${ }^{230} \mathrm{Th}$ in the sediment at the moment it settles (i.e., to the ${ }^{230} \mathrm{Th}$ activity above that of its ${ }^{234} \mathrm{U}$ parent). In the present study, two distinct approaches (and two equations) were used concurrently to calculate this excess. The first one assumes a constant U/Th ratio in the detrital fraction and secular equilibrium conditions within the ${ }^{238} \mathrm{U} /{ }^{234} \mathrm{U} /{ }^{230} \mathrm{Th}$ series. The supported ${ }^{230} \mathrm{Th}$ fraction of the sediment is then a function of the ${ }^{232} \mathrm{Th}$ content [see Lao et al., 1993] (equation (1)). In sediments deprived of significant amounts of diagenetic uranium (as in most of the glacial sequence here) a more "direct" calculation of ${ }^{230} \mathrm{Th}_{\mathbf{x s}}$ can be made by subtracting the ${ }^{234} \mathrm{U}$ activities from the measured ${ }^{230} \mathrm{Th}$ activities [e.g., Hillaire-Marcel et al., 1994b] (equation (2)).

In both cases, an independent chronology is required in order to correct for the radioactive decay of ${ }^{230} \mathrm{Th}_{\mathrm{xs}}$ since deposition.

$$
\begin{aligned}
{ }^{230} \mathrm{Th}_{\mathrm{xs}}= & e^{\lambda t}\left({ }^{230} \mathrm{Th}-\left(\mathrm{Rd}^{* 232} \mathrm{Th}\right)-\left[1 . 1 4 ^ { * } \left({ }^{238} \mathrm{U}-\left(\mathrm{Rd}^{* 232} \mathrm{Th}\right)\right.\right.\right. \\
& \left.\left.\left.\left(1-e^{-\lambda t}\right)\right)\right]\right\} \\
{ }^{230} \mathrm{Th}_{\mathrm{xs}}= & e^{\lambda t}\left({ }^{230} \mathrm{Th}-{ }^{234} \mathrm{U}\right)
\end{aligned}
$$

where ${ }^{230} \mathrm{Th}_{\mathrm{xs}}$ is the initial ${ }^{230} \mathrm{Th}$ excess, $\lambda$ is the ${ }^{230} \mathrm{Th}$ decay constant equal to $9.1929 \times 10^{-6} \mathrm{yr}^{-1}, t$ is the sample age in calendar years, ${ }^{232} \mathrm{Th},{ }^{238} \mathrm{U},{ }^{2307 h}$, and ${ }^{234} \mathrm{U}$ are the measured activities in dpm $\mathrm{g}^{-1}, 1.14$ is the modern seawater ${ }^{234} \mathrm{U} /{ }^{238} \mathrm{U}$ activity ratio [Chen et al., 1986], and $R d$ is the ${ }^{238} \mathrm{U} /{ }^{232} \mathrm{Th}$ activity ratio of the detrital supply (here $0.58 \pm 0.08$; see discussion below).

Thorium-230 fluxes (in dpm $\mathrm{cm}^{-2} \mathrm{kyr}^{-1}$ ) represent the decaycorrected ${ }^{230} \mathrm{Th}_{\mathrm{xs}}$ (expressed in $\mathrm{dpm} \mathrm{g}^{-1}$ ) multiplied by the sediment accumulation rate $\left(\mathrm{g} \mathrm{cm}^{-2} \mathrm{kyr}^{-1}\right)$. Because of to weak constraints on many of the parameters which are involved in the calculations, we consider that ${ }^{230} \mathrm{Th}_{\mathrm{xs}}$ and fluxes are known to no better than $\pm 10 \%$ level of uncertainty (see discussion). These fluxes may provide a first-order estimate of ${ }^{230} \mathrm{Th}$ scavenging rates when advection and lateral transport are negligible. However, in the present context with a strong WBUC carrying the "young" water masses of the NW Atlantic [e.g., Moran et al., 1997] it is risky to assume steady state conditions for ${ }^{230} \mathrm{Th}$ fluxes along continental margins, i.e., to assume that ${ }^{230} \mathrm{Th}$ production rates and scavenging rates are equal and that the system is internally homogeneous. For example, a significant part of the ${ }^{230} \mathrm{Th}$ produced in the Labrador Sea can be exported into the North Atlantic, but an even larger part of the ${ }^{230} \mathrm{Th}$ produced in the Imminger Basin penetrates into the Labrador Sea and settles there (there is apparently more ${ }^{230} \mathrm{Th}$ deposited today in the basin than produced there [Vallières, 1997]). Hopefully, during the glacial episode a reduced outflow prevailed as well as during the $\mathrm{H}$-event themselves.

\section{Results}

\subsection{Sedimentological Features}

The stratigraphy (Figure 2) ${ }^{1}$ for the upper $620 \mathrm{~cm}$ of the study core indicates a high and fairly uniform sedimentation rate throughout the past $\sim 45 \mathrm{kyr}$, with an average of $12.5 \mathrm{~cm}$ $\mathrm{kyr}^{-1}$ [see also Stoner et al., 1996]. Detailed sedimentological studies allowed for the recognition of Heinrich layers $\mathrm{H} 0$ ( Younger Dryas), H1, H2, H3, and $\mathrm{H} 4$ [Hillaire-Marcel et

\footnotetext{
' Supporting data for Figures 2 and 3 are available on diskette or via anonymous FTP from kosmos.agu.org, directory APEND (Username=anonymous, Password=guest). Diskette may be ordered from American Geophysical Union, 2000 Florida Avenue, N.W., DC 20009 or by phone at $800-966-2481 ; \$ 15.00$. Payment must accompany order.
} 

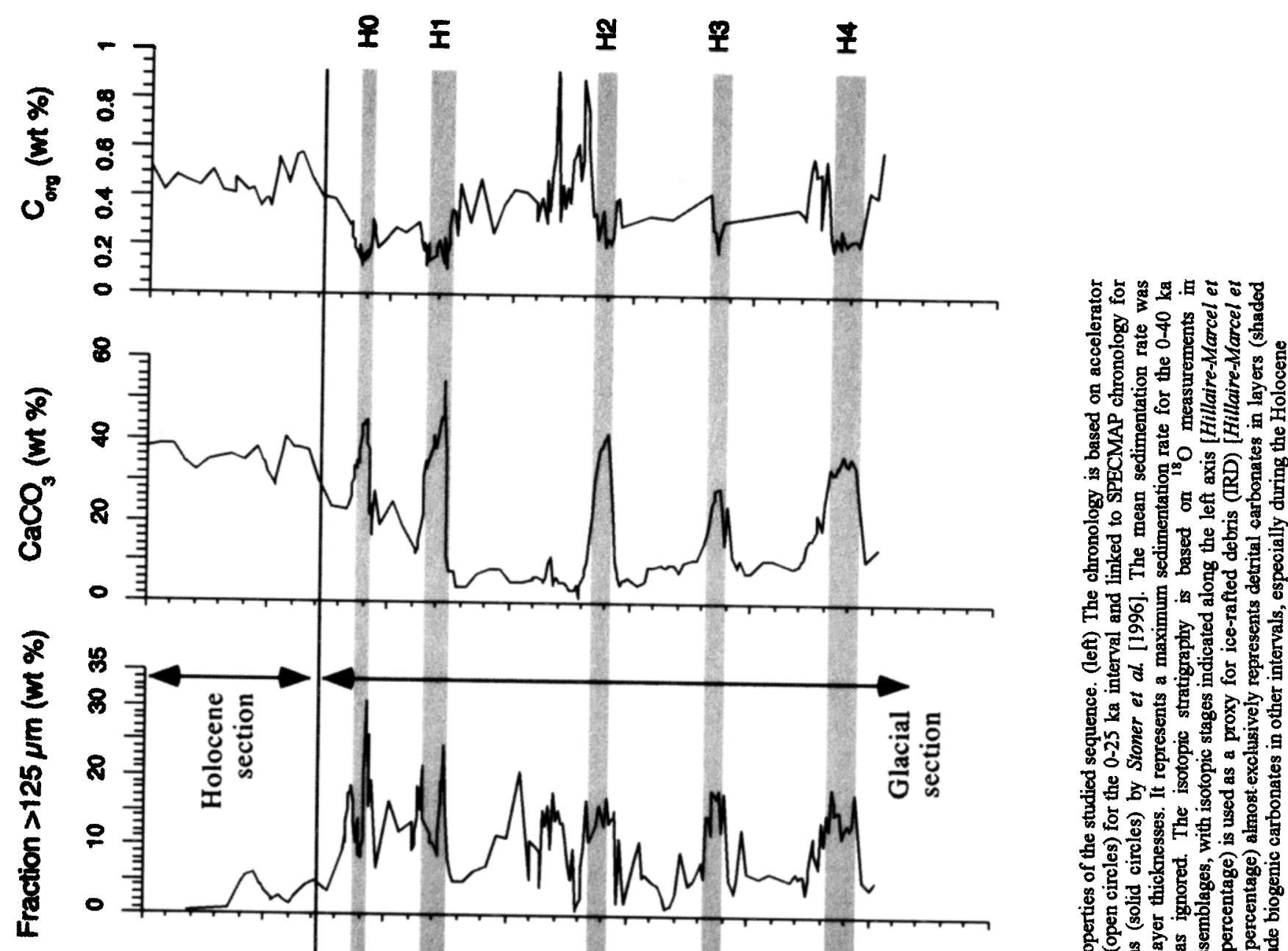

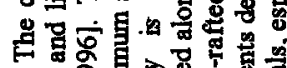

悉要

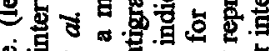

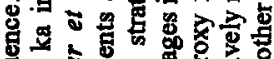

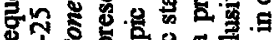

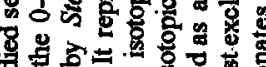

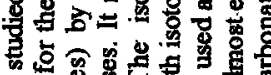

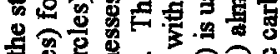
5\% 응

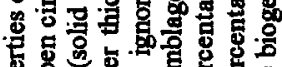

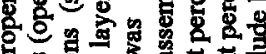

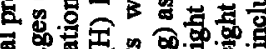

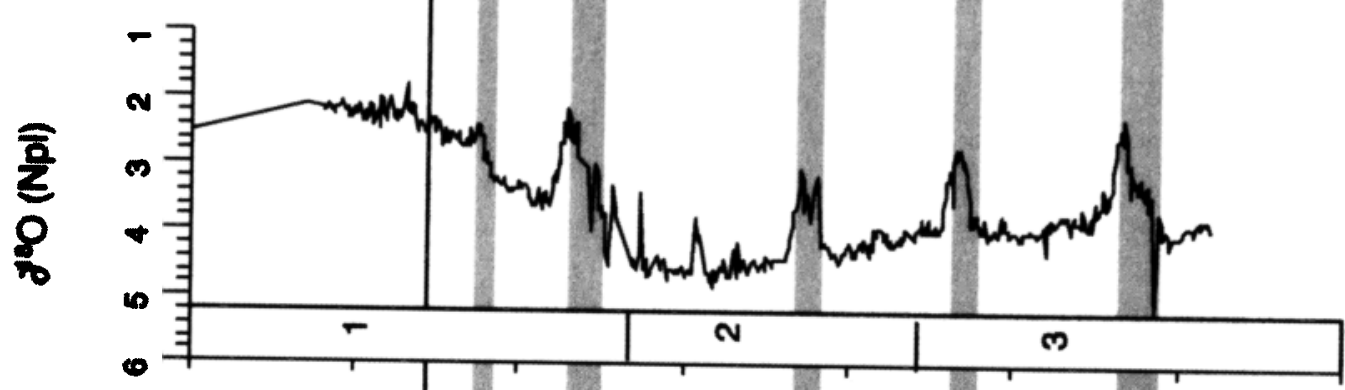

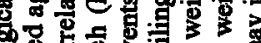

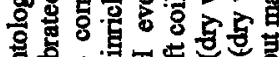

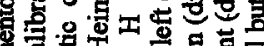

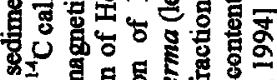

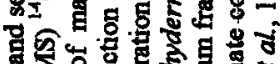
象定

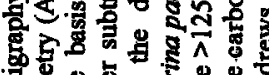

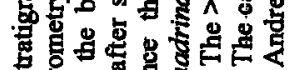

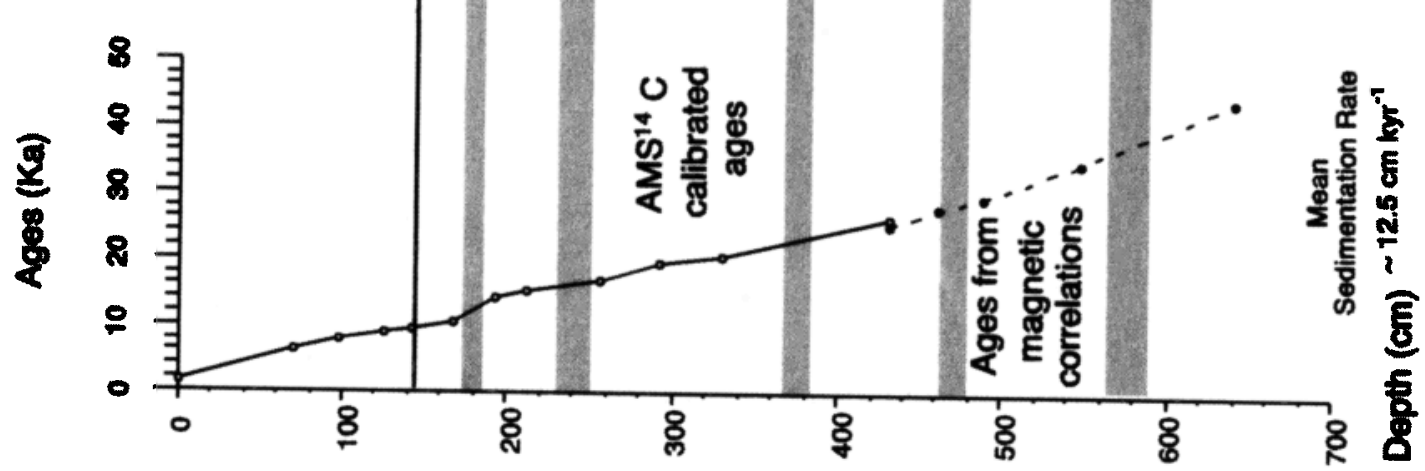

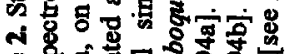

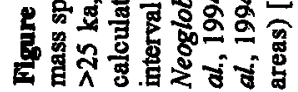


Table 1. Age and Minimum/Maximum Duration From This Study With Calculated Uncertainties

\begin{tabular}{|c|c|c|c|c|}
\hline $\begin{array}{l}\text { Heinrich } \\
\text { Event }\end{array}$ & $\begin{array}{l}\text { Mean Ages, } \\
\mathrm{ka}\end{array}$ & $\begin{array}{c}\text { Duration, } \\
\text { kyr }\end{array}$ & Study Area & Reference $^{a}$ \\
\hline HO & $\begin{array}{l}\sim 11.9^{b} \\
\sim 11.3 \\
\sim 11.5^{b} \\
\sim 10.5\end{array}$ & $\begin{array}{c}0.58 \pm 0.04-0.99 \pm 0.07^{\mathrm{c}} \\
1.3 \sim \mathrm{YD} \\
0.5^{\mathrm{d}}\end{array}$ & $\begin{array}{c}\text { SW Labrador Sea }\left(50^{\circ} \mathrm{N}, 45^{\circ} \mathrm{W}\right) \\
\text { Off Nova Scota }\left(43^{\circ} \mathrm{N}, 56^{\circ} \mathrm{W}\right) \\
\text { Greenland Ice Sheet Project } 2(\mathrm{GISP} 2)\left(72^{\circ} \mathrm{N}, 38^{\circ} \mathrm{W}\right) \\
\text { Outlet of St. Lawrence Gulf }\end{array}$ & $\begin{array}{l}1 \\
2 \\
3 \\
4\end{array}$ \\
\hline $\mathrm{H} 1$ & $\begin{array}{l}\sim 16^{b} \\
\sim 13.8 \\
\sim 13.9 \\
\sim 14.3 \\
\sim 17.5^{b} \\
\sim 14.5\end{array}$ & $\begin{array}{c}0.83 \pm 0.06-1.41 \pm 0.09^{\mathrm{c}} \\
1.2^{\mathrm{d}} \\
2^{\mathrm{c}} \\
0.6^{\mathrm{c}} \\
1.4^{\mathrm{d}} \\
0.25-1.25\end{array}$ & $\begin{array}{c}\text { SW Labrador Sea }\left(50^{\circ} \mathrm{N}, 45^{\circ} \mathrm{W}\right) \\
\text { North Atlantic }\left(40-55^{\circ} \mathrm{N}\right) \\
\text { Armorican Seamount }\left(46^{\circ} \mathrm{N}, 12^{\circ} \mathrm{W}\right) \\
\text { North Atlantic }\left(42^{\circ} \mathrm{N}, 31^{\circ} \mathrm{W}\right) \\
\text { NW Labrador Sea }\left(62^{\circ} \mathrm{N}, 62^{\circ} \mathrm{W}\right) \\
\text { North Atlantic and Labrador Sea } \\
\text { North Atlantic }\left(47-59^{\circ} \mathrm{N}, 20^{\circ} \mathrm{W}\right) \\
\text { North Atlantic }\left(40-60^{\circ} \mathrm{N}\right)\end{array}$ & $\begin{array}{c}1 \\
5 \\
6 \\
7 \\
8 \\
9 \\
10 \\
11\end{array}$ \\
\hline H2 & $\begin{array}{l}\sim 20.4 \\
\sim 21 \\
\sim 25.1^{b} \\
\sim 21.1\end{array}$ & $\begin{array}{c}077 \pm 0.05-1.31 \pm 0.08^{\circ} \\
1.6^{\mathrm{d}} \\
1.1^{\mathrm{c}} \\
0.8^{\mathrm{e}} \\
2.1^{\mathrm{d}} \\
0.25-1.25\end{array}$ & $\begin{array}{c}\text { SW Labrador Sea }\left(50^{\circ} \mathrm{N}, 45^{\circ} \mathrm{W}\right) \\
\text { North Atlantic }\left(40-55^{\circ} \mathrm{N}\right) \\
\text { Armorican Seamount }\left(46^{\circ} \mathrm{N}, 12^{\circ} \mathrm{W}\right) \\
\text { North Atlantic }\left(42^{\circ} \mathrm{N}, 31^{\circ} \mathrm{W}\right) \\
\text { NW Labrador Sea }\left(62^{\circ} \mathrm{N}, 62^{\circ} \mathrm{W}\right) \\
\text { North Atlantic and Labrador Sea } \\
\text { North Attantic }\left(47-59^{\circ} \mathrm{N}, 20^{\circ} \mathrm{W}\right) \\
\text { North Atlantic }\left(40-60^{\circ} \mathrm{N}\right)\end{array}$ & $\begin{array}{c}1 \\
5 \\
6 \\
7 \\
8 \\
9 \\
10 \\
11\end{array}$ \\
\hline $\mathrm{H3}$ & $\begin{array}{l}\sim 28.2^{b} \\
\sim 27.1 \\
\sim 28 \\
\sim 31.2^{b}\end{array}$ & $\begin{array}{c}0.87 \pm 0.05-1.48 \pm 0.07^{c} \\
1.5^{\mathrm{d}}\end{array}$ & $\begin{array}{l}\text { SW Labrador Sea }\left(50^{\circ} \mathrm{N}, 45^{\circ} \mathrm{W}\right) \\
\text { North Atlantic }\left(40-55^{\circ} \mathrm{N}\right) \\
\text { North Atlantic and Labrador Sea } \\
\text { North Atlantic }\left(47-59^{\circ} \mathrm{N}, 20^{\circ} \mathrm{W}\right)\end{array}$ & $\begin{array}{c}1 \\
5 \\
9 \\
10\end{array}$ \\
\hline H4 & $\begin{array}{l}\sim 35.7^{b} \\
\sim 35.2 \\
\sim 41 \\
\sim 43.1^{b}\end{array}$ & $\begin{array}{c}1.26 \pm 0.08-2.14 \pm 0.12^{c} \\
2^{d} \\
>0.7^{c}\end{array}$ & $\begin{array}{l}\text { SW Labrador Sea }\left(50^{\circ} \mathrm{N}, 45^{\circ} \mathrm{W}\right) \\
\text { North Atlantic }\left(40-55^{\circ} \mathrm{N}\right) \\
\text { Armorican Seamount }\left(46^{\circ} \mathrm{N}, 12^{\circ} \mathrm{W}\right) \\
\text { North Atlantic and Labrador Sea } \\
\text { North Atlantic }\left(47-59^{\circ} \mathrm{N}, 20^{\circ} \mathrm{W}\right)\end{array}$ & $\begin{array}{c}1 \\
5 \\
6 \\
9 \\
10\end{array}$ \\
\hline
\end{tabular}

\footnotetext{
Age and/or duration from 1, this study; 2, Keigwin and Jones [1995]; 3, Dansgaard et al. [1982]; 4, de Vernal et al. [1996]; 5, Vidal et al. [1997]; 6, Thomson et al. [1995]; 7, Francois and Bacon [1994]; 8, Andrews et al. [1994]; 9, Bond et al. [1992]; 10, Monighetti et al. [1995]; 11 , Dowdeswell et al. [1995].

${ }^{b}$ Time of deposition and duration based on calibrated ages.

Time of deposition and duration based on ${ }^{14} \mathrm{C}$ dates.

d Time of deposition and duration based on ${ }^{230} \mathrm{Th}_{\mathrm{xs}}$ approaches.
}

al., 1994a; Fagel et al., 1996; Stoner et al., 1996, 1998]. Their thickness is $\sim 11, \sim 20, \sim 16, \sim 12$, and $\sim 29 \mathrm{~cm}$, respectively. Their interpolated mean ages are $\sim 11.9, \sim 16.0, \sim 22.8, \sim 28.2$, and 35.7 cal. kyr, respectively (Table 1) [see also Stoner et al., 1996]. Some discrepancies are observed with the ages reported elsewhere for these events, especially for the interval $>25$ cal. kyr. They are caused by bias in correlating time series and/or by ${ }^{14} \mathrm{C}$ timescale problems [Kitagawa and van der Plicht, 1998; Stoner et al., 1998]. Nevertheless, these anomalies are of minor incidence in the calculation of initial ${ }^{230} \mathrm{Th}_{\mathrm{xs}}$ (in comparison with the ${ }^{230} \mathrm{Th}$ half-life of $\sim 75,400$ years).

In the planktonic oxygen isotope record (Figure 2), FDUs are characterized by small shifts to lighter values, notably toward the top of the units. They represent major seasurface dilution events linked to large iceberg-melting episodes and/or episodes with major glacial meltwater pulses. These shifts in $8^{18} \mathrm{O}$ values generally match peaks in the coarse fraction content (>125 $\mu \mathrm{m}$; Figure 2), which indicates enhanced IRD. Another remarkable feature is the overall high carbonate content of the Holocene section $(-35-40 \%)$ in contrast with the much lower values of the glacial interval $(\leq 10 \%)$, except for the FDU themselves, for which $\mathrm{CaCO}_{3}$ contents are as high as $60 \%$ (Figure 2). Most of the Holocene carbonates correspond to a fine biogenic micrite linked to Coccolithophoridae production [see Hillaire-Marcel et al., 1994b], whereas the pre-Holocene carbonates are essentially detrital in origin and are derived from glacial erosion of Paleozoic limestone in the Hudson Strait region [Andrews et al., 1994]. The sediment shows a relatively uniform Corg content that varies slightly between 0.3 and $0.5 \%$ (Figure 2 ), except for FDU where lower values are observed $(\leq 0.2 \%)$.

In P-094 all $\mathrm{H}$ layers display several common features (high carbonate content, low Corg, high coarse fraction, top light peak in ${ }^{18} \mathrm{O}$, etc.), but also show discrete differences. In $\mathrm{HO}$, $\mathrm{H}$, and to a lesser extent, $\mathrm{H} 4$ the coarse fraction content 
shows two peaks encompassing the high detrital carbonate pulse (Figure 2). This feature is not as clear in $\mathrm{H} 2$ and $\mathrm{H} 3$ either because it has never been recorded or because of artifacts (differences in biological mixing, variable penetration of IRD in the sediment, etc.). Other minor differences are observed, such as the maximum detrital carbonate contents, with values $\geq$ $40 \%$ in $\mathrm{HO}, \mathrm{H1}$, and $\mathrm{H} 2$ in contrast with lower maximums in $\mathrm{H} 3$ and $\mathrm{H} 4$ ( 25 and $35 \%$ respectively).

\subsection{U and Th Series Data}

As shown in Figure 3 , mean sediment $U$ concentrations reported on a carbonate-free basis are $2.34 \pm 0.60$ and $2.06 \pm$ $0.54 \mu \mathrm{g} \mathrm{g}^{-1}$ for the Holocene and the glacial sections ( $H$ layers excluded), respectively. The mean Th concentrations suggest homogeneous detrital silicate sources through time, with almost identical mean values of $9.9 \pm 1.3$ and $10.2 \pm 2.1 \mu \mathrm{g} \mathrm{g}^{-1}$ for the Holocene and the glacial sections, respectively. Note that these are carbonate-free sediment values and that $H$ layers were excluded from the calculation. In contrast, significant differences are observed within and between $H$ layers. For example, $\mathrm{H} 4, \mathrm{H} 3$, and $\mathrm{H} 2$ are characterized by low Th and $\mathrm{U}$ ( $\mathrm{CaCO}_{3}$-free) concentrations of $\sim 8$ and $\sim 1.5 \mu \mathrm{g} \mathrm{g}^{-1}$ respectively. They contrast with $\mathrm{HO}$ and $\mathrm{Hl}$ which have much higher contents of these elements $\left(\sim 11\right.$ and of $\sim 2.4 \mu \mathrm{g} \mathrm{g} \mathrm{g}^{-1}$, respectively, i.e., values slightly exceeding those of the mean glacial sediment (Figure 3 )).

Throughout most of the glacial sequence, ${ }^{234} U /{ }^{238} U$ ratios lower than 1.0 indicate that the sediment has undergone $U$ losses with preferential departure of ${ }^{234} \mathrm{U}$. During the Holocene, particularly the upper half, this ratio gets closer to the oceanic value $(\sim 1.14)$ [Chen et al., 1986]. This indicates diagenetic $U$ uptake linked to enhanced organic carbon fluxes in the interval, which in turn induced low Eh conditions in the sediment and $U$ precipitation a few centimeters below the sediment surface [e.g., Gariépy et al., 1994]. A few peaks with ${ }^{234} U$ excesses (versus ${ }^{238} U$ ) are observed downcore, especially in $\mathrm{H} 2$ and $\mathrm{H} 4$. In $\mathrm{H} 4$, notably, $\mathrm{a}^{234} \mathrm{U} /{ }^{238} \mathrm{U}$ ratio as high as 1.6 has been measured. This very unusual value, at least in the deep Labrador Sea sediments [see Vallieres, 1997], also corresponds to a very high and unusual $\delta^{18} \mathrm{O}$ value of $\mathrm{Npl}$ assemblages $(+5.2 \%$ ) therefore suggesting the incorporation of reworked material, the origin of which can only be speculative.

\subsection{Initial Excesses of ${ }^{230} \mathrm{Th}$ and ${ }^{230} \mathrm{Th}$ Fluxes}

Both the ${ }^{230} \mathrm{Th}_{\mathrm{xs}}$ and ${ }^{230} \mathrm{Th}$ fluxes (Figure 3) show significant increases during the Holocene compared with glacial values. These increases match higher biogenic carbonate fluxes and reach maximum values of $\sim 4 \mathrm{dpm} \mathrm{g}^{-1}$ and $\sim 30 \mathrm{dpm} \mathrm{cm}^{-2} \mathrm{kyr}^{-1}$, respectively. These high ${ }^{230} \mathrm{Th}_{\mathrm{x}}$ and ${ }^{230} \mathrm{Th}$ fluxes also correspond to an intensified WBUC [see Andrews et al., 1994; Hillaire-Marcel et al., 1994a; Fagel et al., 1997]. The enhanced biogenic and detrital particulate fluxes of the Holocene are linked to lateral supplies by this current [e.g., Hillaire-Marcel et al., 1994b; Fagel et al., 1997]. This also results in enhanced ${ }^{230} \mathrm{Th}_{\mathrm{xs}}$ fluxes. In the glacial part of the sequence, mean values of $1.29 \pm 0.04 \mathrm{dpm} \mathrm{g}^{-1}$ and of $15.22 \pm 0.45$ $\mathrm{dpm} \mathrm{cm}^{-2} \mathrm{kyr}^{-1}$, were calculated for ${ }^{230} \mathrm{Th}_{\mathrm{m}}$ and ${ }^{230} \mathrm{Th}$ fluxes, respectively. These values are about half of those of the Holocene. However, the low glacial mean ${ }^{230} \mathrm{Th}$ flux of $\sim 15$ dpm $\mathrm{cm}^{-2} \mathrm{kyr}^{-1}$ is still greater than the theoretical vertical production of ${ }^{230} \mathrm{Th}$ flux in the overlying water column, i.e., $8.96 \mathrm{dpm} \mathrm{cm}^{-2} \mathrm{kyr}^{-1}$, based on a production of $2 . \mathrm{dpm} \mathrm{cm}^{-2} \mathrm{kyr}^{-1}$ of ${ }^{230} \mathrm{Th}$ for each kilometer of water [e.g., Cochran, 1982]. This difference provides supporting evidence for reduced but likely steady sediment and ${ }^{230} \mathrm{Th}$ lateral supplies during the glacial period and therefore for some residual outflow of the WBUC. Additional evidence for a residual lateral flux comes from the presence of smectites in the glacial sediment (35\%) [Fagel et al., 1996], which, although not as abundant as in the Holocene sequence, indicates the occurrence of long distance particulate transport from the Irminger Basin/Ridge area. Finally, ${ }^{230}$ Th sedimentary fluxes during $\mathrm{H}$ events may reach

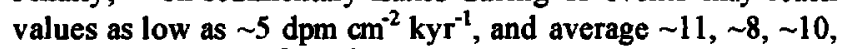
$\sim 17$, and $\sim 9 \mathrm{dpm} \mathrm{cm}^{-2} \mathrm{kyr}^{-1}$ (Figure 3), for HO, H1, H2, H3, and $\mathrm{H} 4$, respectively. These low values are indicative of the very high sedimentation rates of these layers linked to enhanced IRD in addition to the input of detrital carbonates overspilled from the NAMOC [Stoner et al., 1996].

\section{Discussion}

\subsection{Constraints on the Calculation of ${ }^{230} \mathrm{Th}_{\mathrm{xs}}$}

Two different approaches are used to calculate the "unsupported" ${ }^{230} \mathrm{Th}$ fraction of the sediment. Both have limitations. The method which uses the ${ }^{232} \mathrm{Th}$ content as a mean to quantify the fraction of ${ }^{230} \mathrm{Th}$ strictly linked to the detrital fraction implies that the U-Th systematics of this fraction remain constant through time. For P-094 this assumption requires further examination for the following reasons: (1) the IRD component of the detrital fraction likely has various origins with distinct U-Th signatures [see also Vallières, 1997]; (2) the sediment contains variable amounts of reworked carbonates deprived of significant amounts of ${ }^{232} \mathrm{Th}$ [Vallières, 1997] but which may contain $U$ series isotopes with, in principle, activity ratios close to secular equilibrium; and (3) the U-Th systematics of the fine fraction of the sediment depends on grain size and mineralogical composition [e.g., Vallieres, 1997], which, in turn, are largely controlled here by the outflow of the WBUC [Fagel et al., 1996].

With respect to the second constraint it is worth mentioning the fact that in the glacial sediment the addition of detrital carbonates (Figure 4a) does not apparently add significant amounts of "detrital" $U$ into the system (Figure 4b). However, a more detailed examination of some of the $H$ layers (notably $\mathrm{HO}$ and $\mathrm{H1}$ ) shows that this observation is not always true. Nevertheless, changes in the IRD sources may indeed alter the U-Th signature of the detrital fraction, as shown by oscillations of the U/Th ratio and concurrent fluctuations in the coarse fraction content, notably at the bases and tops of $H$ layers (Figure 3 ). This could result in a few abnormal ${ }^{230} \mathrm{Th}_{\mathrm{x}}$ values at specific depths downcore. Otherwise, ${ }^{230} \mathrm{Th}_{\mathrm{xs}}$ values based on this approach should generally show consistency, as suggested by the narrow range of ${ }^{238} U /{ }^{232} \mathrm{Th}$ ratios in the glacial sediment $(0.58 \pm 0.08$; Figure 3). This is the ratio which was used to derive ${ }^{230} \mathrm{Th}_{\mathrm{x}}$ based on this approach (see (1) above). The large standard deviation of this ratio linked to the variability of (IRD/hemipelagic sediment) ratio represents the largest uncertainty in this method compared with the $\pm 3 \%$ counting errors which, although almost negligible, were taken into account. 


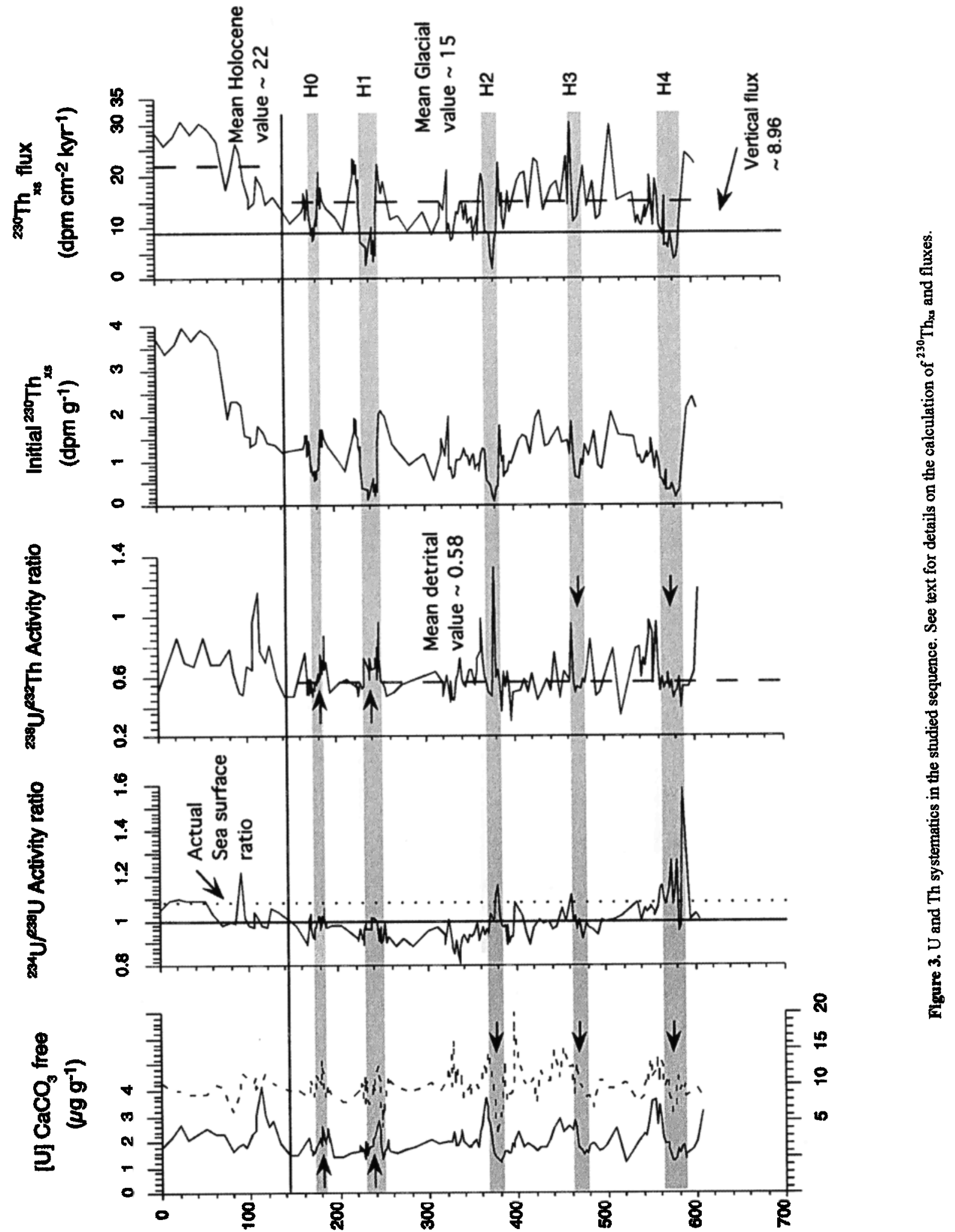



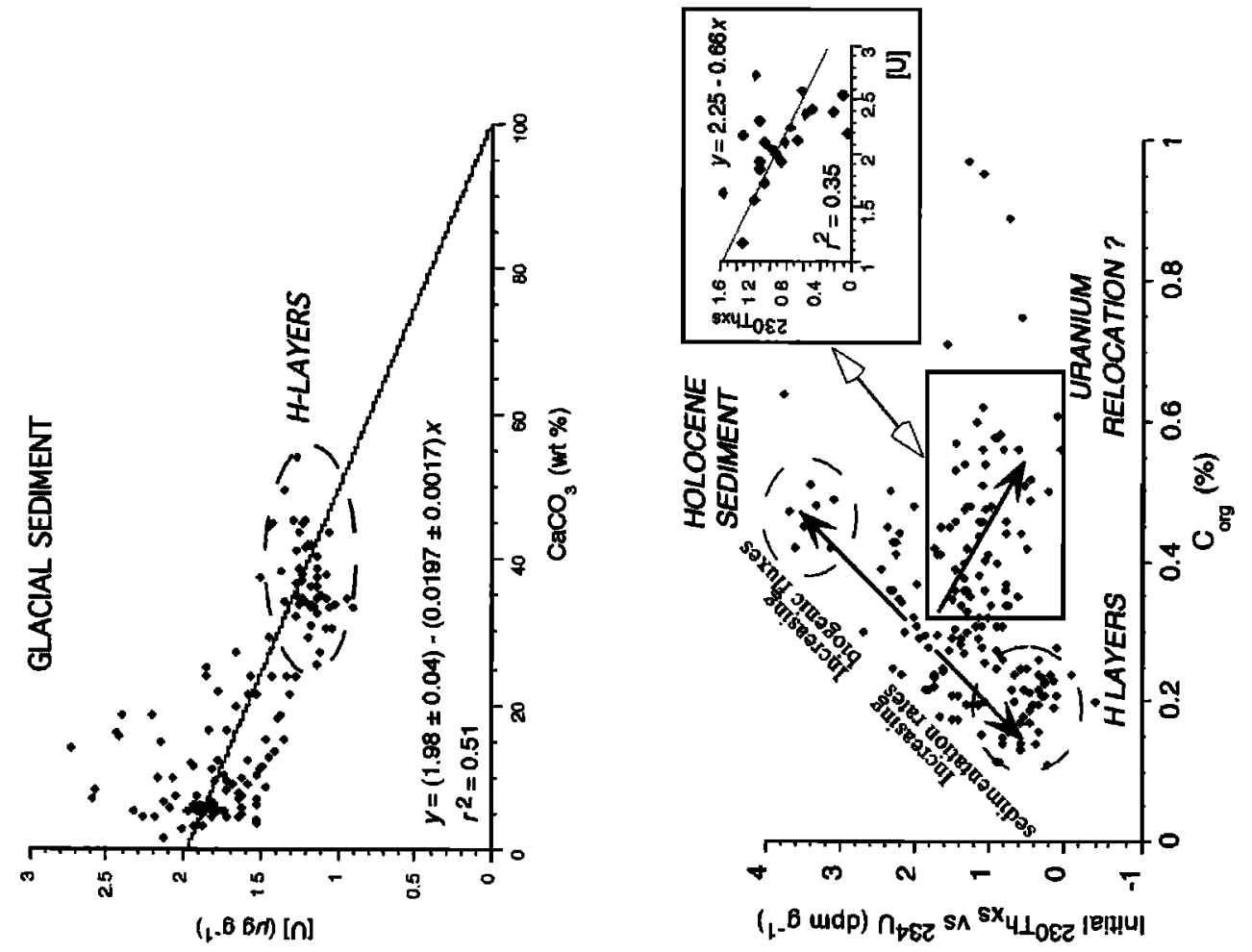

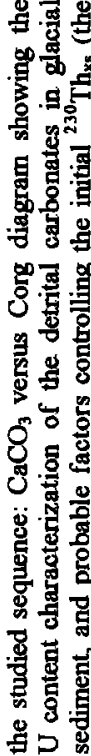
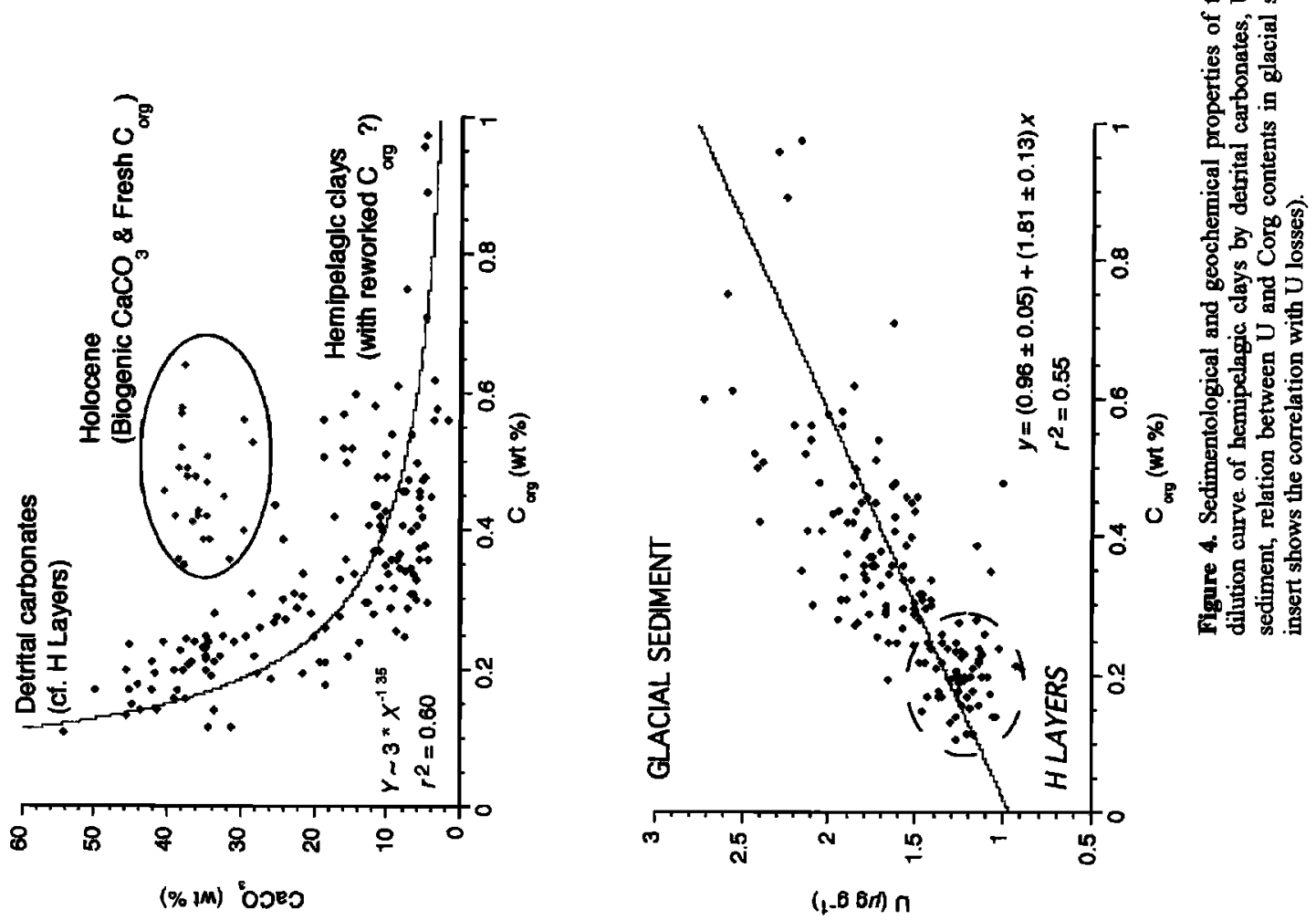


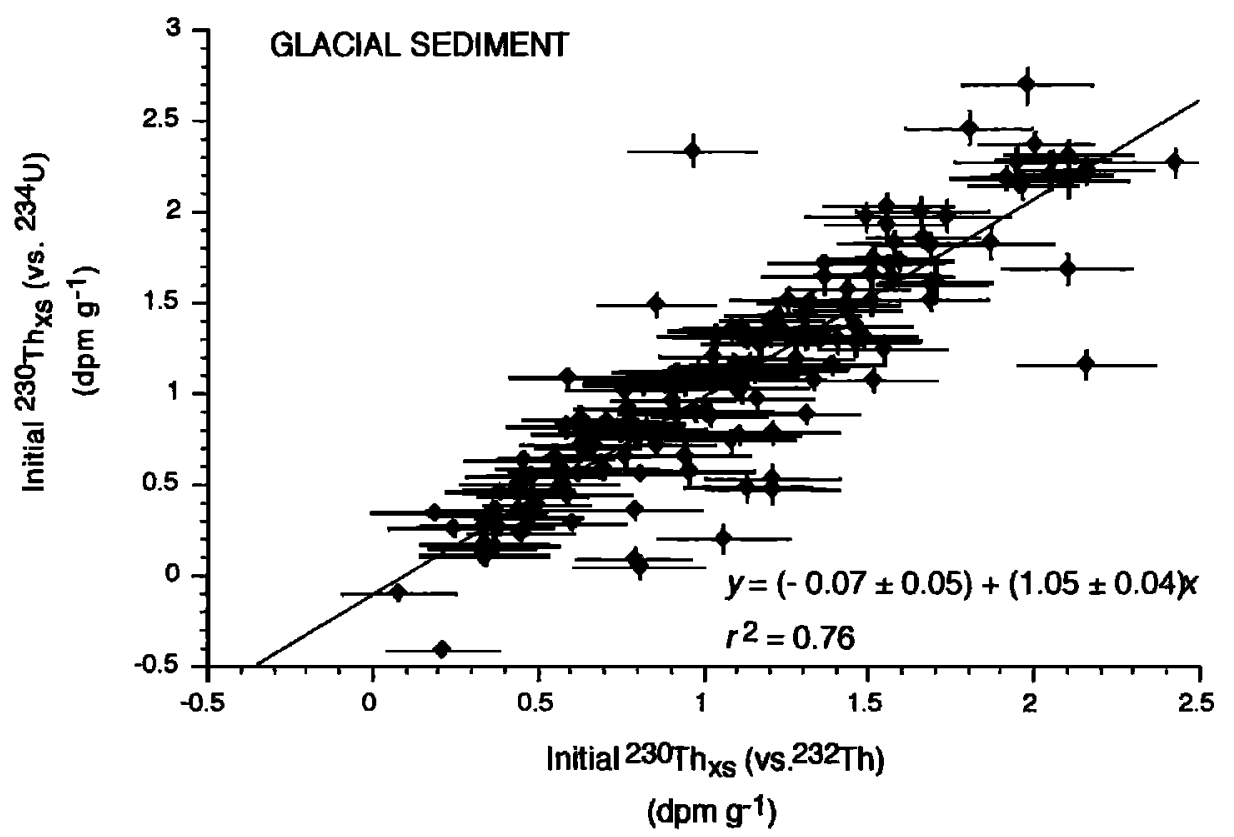

Figure 5. Correlation of ${ }^{230} \mathrm{Th}_{\mathrm{xs}}$ calculated either from ${ }^{2.34} \mathrm{U}(y)$ or ${ }^{2.32} \mathrm{Th}(x)$ data (see text for explanations on the calculation methods).

A more direct calculation of ${ }^{230} \mathrm{Th}_{\mathrm{xs}}$ based on ${ }^{234} \mathrm{U}$ activity can be considered for sediments deprived of significant amounts of diagenetic $U$, but it also has its limitations. First, this approach also implies secular equilibrium between $U$ series isotopes in the detrital fraction. Unfortunately, detrital particles often show an inherited excess in ${ }^{230}$ Th that is linked to $U$ losses either by former inland weathering processes, in soils notably [e.g., Vallières et al., 1993], or by leaching during transport. This should not be a major issue here for the glacial sediment which originated from mechanical erosion of surrounding lands, except for the small percentage (versus the total sediment) of long distance clays transported from the Reykjanes Ridge [see Piper, 1988; Andrews et al., 1994; Fagel et al., 1997]. Second, another limiting factor in the calculation of ${ }^{230} \mathrm{Th}_{\mathrm{x}}$ based on ${ }^{234} \mathrm{U}$ data is the possible occurrence of postdepositional $U$ mobility in the sequence. Deep-sea sediments often reveal successions of layers with contrasting Eh gradients linked to differences in organic carbon content and/or in sedimentation rates that allow secondary U relocation to occur at oxic/postoxic boundaries [e.g., Bonatti et al., 1971; Vallieres, 1997; Thomson et al., 1998]. A discrete $U$ relocation between the (likely oxidized) $\mathrm{H}$ layers and the (reduced) interlayered hemipelagic clays cannot be ignored. Peaks in U content are seen notably at the top and bottom of most $\mathrm{H}$ layers (Figure 3). They could represent such secondary $U$ relocation sites. In the present case, ${ }^{234} U /{ }^{238} U$ activity ratios vary within a narrow range and cannot be unequivocally linked to this process (Figure 3), but this does not necessarily preclude such a link. As a matter of fact, the abundant detrital carbonates observed in $\mathrm{H}$ layers behave like a dilutant of a Corg-rich, carbonate-poor (silty clay) end-member (Figure 4a). A direct proportionality seems to characterize the Corg- $U$ content relationship of this system
(Figure 4c). This could simply indicate that the $U$ content of the noncarbonate detritral fraction is proportional to the organic matter content. However, when examining the Corg-U relationship, another interpretation may be put forward (Figures $4 \mathrm{c}$ and $4 \mathrm{~d}$ ). The $U$ content trend of the U-rich layers is (weakly) inversely correlated with the ${ }^{230} \mathrm{Th}_{\mathrm{xs}}$. This pattern probably arises from $U$ redistribution processes at $H$ layer boundaries, although one cannot totally discard the possibility that sedimentological changes could account for it.

From the above discussion it is true that neither of the two methods of calculating ${ }^{230} \mathrm{Th}_{\mathrm{xs}}$ is problem-free, although the two results are reasonably consistent (Figure 5). The slope of the regression line between $\left(y={ }^{234} U\right.$-derived $\left.{ }^{230} \mathrm{Th}_{\mathrm{xs}}\right)$ and $(x$ $={ }^{232} \mathrm{Th}$-derived $\left.{ }^{230} \mathrm{Th}_{\mathrm{xs}}\right)$ is slightly greater than unit within statistical limits $(1.05 \pm 0.04)$. This is probably due to the fact that most of the glacial sediment ( $\mathrm{H}$ layers excepted) is depleted in ${ }^{234} U$ with respect to ${ }^{238} U$ (Figure 3). The detrital fraction may thus have been slightly enriched in ${ }^{230} \mathrm{Th}$ (versus ${ }^{234} \mathrm{U}$ ) by a maximum of $\sim 5 \pm 4 \%$. Nevertheless, for the purpose of integrating ${ }^{230} \mathrm{Th}_{\mathrm{xs}}$ through time (Figure 3) we used the ${ }^{232} \mathrm{Th}$-based method (equation (1)) throughout most of the sequence, rather than the ${ }^{234} U$-based approach (equation (2)) because one of our major concerns was the possible postdepositional $U$ mobility at $H$ layer boundaries, i.e., at critical locations with respect to our major objective. We made an exception for $\mathrm{HO}$ and $\mathrm{Hl}$ layers for which we used (2) because of the possibility that their detrital carbonate fraction may have added significant amounts of detrital $U$ (with its ${ }^{230}$ Th daughter isotope). This possibility was suggested by the fact that their $U$ contents and $U / T h$ ratios are much higher than those of the other $\mathrm{H}$ layers (Figure 3 ). 


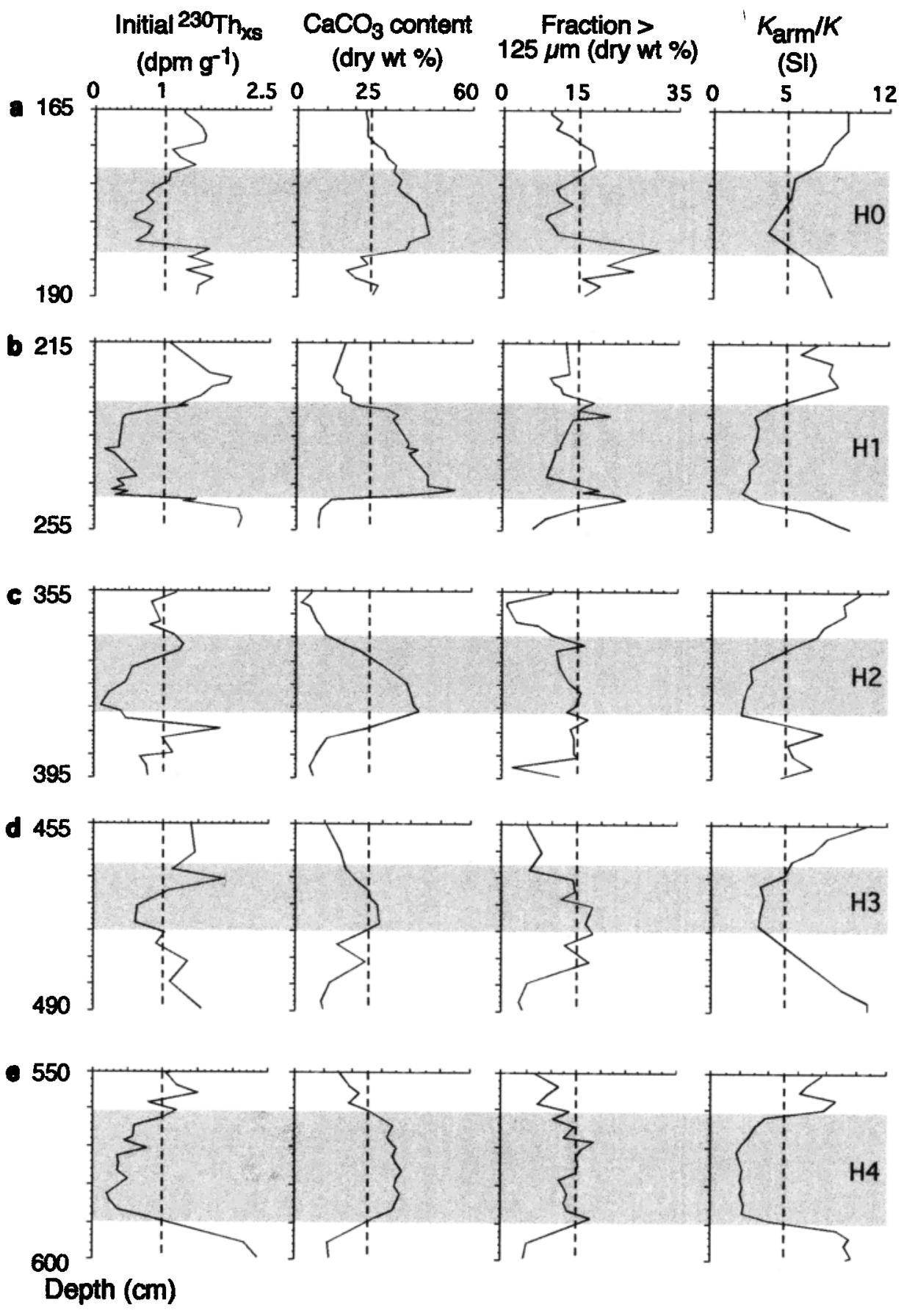

Figure 6. Detailed examination of $\mathrm{H}$ layer properties with respect to diagnostic sedimentological features and ${ }^{230} \mathrm{Th}_{\mathrm{xs}}$ data: (a) HO ( Younger Dryas), (b) H1, (c) H2, (d) H3, and (e) H4. Shaded areas represent the H layers delimited by visual criteria.

\subsection{Boundaries and Structure of Heinrich Layers}

The precise definition of $\mathrm{H}$ layers is difficult when investigating $H$ events in sequences where contrasting sedimentological regimes prevailed. In core P-094, H layers (H0-H4) all include a carbonate-rich subunit within an interval marked by a maximum in the grain size fraction $>125$ $\mu \mathrm{m}$ (Figures 3 and 6 ). In the late Quaternary sediments of the Labrador Sea this large size fraction is mainly composed of IRD with a few foraminifer shells. Its relative abundance may thus be used as a first-order index for IRD supply [HillaireMarcel et al., 1994a]. The detrital carbonates originate from glacial erosion of the Paleozoic limestone in the Ungava BayHudson Strait area [Andrews et al., 1995]. The fact that all $\mathrm{H}$ layers (from $\mathrm{H} 4$ to $\mathrm{H} 0$ ) in core P-094 contain such abundant detrital carbonates suggests that at least a large part of iceberg discharges originated from the same source area during each of the corresponding depositional events. This conclusion is in agreement with the observation made by Bond and Lotti 
[1995] that the Laurentidian Ice Sheet (LIS) was a source for H3 in addition to the eastern Greenland supply proposed by Grousset et al. [1993]. Nevertheless, H layers show small differences in their sedimentological features. $\mathrm{HO}$ and $\mathrm{HI}$ layers, which have already been distinguished from $\mathrm{H} 2$ to $\mathrm{H} 4$ on the basis of their U-Th systematics, also show a higher detrital carbonate content. Furthermore, they are the only events clearly recorded in the sequence by two coarse fraction peaks encompassing the detrital carbonate layer (Figure 6). According to Alley and MacAyeal [1994], such a sequence of two distinct pulses could be interpreted as the result of the binge and purge mechanism of ice dome glaciers. Here some of the $\mathrm{H}$ layers also show an erosional surface below the bottom coarse fraction peak (notably $\mathrm{H} 3$ and $\mathrm{H} 6$ ) [cf Hillaire-Marcel et al., 1994a; Stoner et al., 1996], suggesting that at least for some of the events, two distinct mechanisms could be involved in the deposition of the coarse fraction: deep gravity flows (bottom peak) and IRD (top peak). Whether such processes occurred systematically during all events is speculative because other factors could have disturbed the signal. For example, during their settling, heavy coarse icerafted particles could penetrate more or less deeply into the underneath hemipelagic clay, resulting in sedimentological bias in the definition of unit boundaries. As a consequence, it should not be surprising that the visually defined boundaries of $\mathrm{H}$ layers (shaded layers in all figures) generally encompass the FDU strictly defined on the basis of low ${ }^{230} \mathrm{Th}_{\mathrm{xs}}$ values $(<1$ $\mathrm{dpm} \mathrm{g}^{-1}$ ). Therefore one cannot totally discard the possibility of bias in the calculation of $\mathrm{H}$ event duration. As shown in Figure 6, we combined ${ }^{230} \mathrm{Th}_{\mathrm{xa}}, \mathrm{CaCO}_{3}$ content, coarse fraction content, and a constructed magnetic parameter $\left(K_{\mathrm{arm}} / K\right)$ (as determined by Stoner et al. [1996]) to define the boundaries of the layers. The $K_{\text {arm }} / K$ parameter has been shown to respond inversely to magnetic grain size when the magnetic minerals are dominated by magnetite. A significant decrease in $K_{\mathrm{arm}} / K$ values is observed in all $H$ layers, suggesting a correlative increase of magnetite grain size [Grousset et al.,1993; Stoner et al.,1996]. In $\mathrm{Hl}$ and $\mathrm{H} 4$ layers the sharp shifts in $K_{\mathrm{arm}} / K$ values at the top and bottom of each unit coincide with the visual boundaries which were used here to define the layers. In $\mathrm{H} 0-\mathrm{H} 2$ and $\mathrm{H} 3$ more gradual decreases in $K_{\text {arm }} / K$ values are observed. These more diffuse $K_{\mathrm{arm}} / K$ boundaries may be due either to the sedimentological processes themselves or to possible postdepositional disturbances as noticed elsewhere (e.g., bioturbation) [Francois and Bacon, 1994; Thomson et al., 1995]. As a matter of fact, mixing due to bioturbation cannot be ignored, especially at the top of $\mathrm{H}$ layers. Discrete evidence for such a process, in HO notably, is found in the smoothed transitions for most sedimentological parameters at the top of the layer contrasting with the sharp gradients at the bottom of it (Figure 6). Conclusive evidence for some mixing by bioturbation on top of $\mathrm{HO}$ is given by ${ }^{14} \mathrm{C}$ age discrepancies between two monospecific assemblages. At precisely $175 \mathrm{~cm}$ downcore (i.e., right on top of H0; Figure 6), Globigerina bulloides (Gb) shells yielded an age of $9790 \pm 150 \mathrm{ka}$ (corrected for reservoir effect) to compare with an age of $10420 \pm 90 \mathrm{ka}$ on $\mathrm{Npl}$ shells from this very layer. We are thus lead to conclude that the $\mathrm{Gb}$ shells were injected from the overlaying hemipelagic clay into the HO sediment. Actually, the $\mathrm{Gb}$ population developed slightly after the H0-Younger
Dryas episode, i.e., when the early Holocene warmer sea surface conditions were attained [see de Vernal et al., 1998]. For $\mathrm{H}$ events older than $\mathrm{HO}$ and due to the harsh glacial conditions of the area [de Vernal et al., 1998], low benthic organic carbon fluxes prevailed and resulted in reduced benthic life, thus in minimum mixing by bioturbation. A lesser influence of such effects on top of the other studied $H$ layers is indicated by the generally much sharper sedimentological gradients observed at their upper boundary (Figure 6) compared with that of $\mathrm{HO}$. Therefore we will retain the limits of the $\mathrm{H}$ layers as defined above (i.e., $\mathrm{CaCO}_{3}$ color peak boundaries), which remain the best definition for the layer boundaries within the inherent uncertainty of such a deep-sea record.

\section{3. ${ }^{230} \mathrm{Th}_{\mathrm{m}}$ Duration of $\mathrm{H}$ Events}

In order to estimate the duration of each $\mathrm{H}$ event fom $\mathrm{H} 0$ to $\mathrm{H} 4$ we calculated ${ }^{230} \mathrm{Th}_{\mathrm{xs}}$ inventories in the corresponding $\mathrm{H}$ layers (as delimited above) and divided these inventories by the ${ }^{230} \mathrm{Th}$ flux. We calculated confidence intervals for the inventories using standard errors. However, an empirical $\pm 10 \%$ estimate would be more reasonable taking into account all uncertainties. As a matter of fact, the largest uncertainties in the assessment of the $\mathrm{H}$ event duration lie in the difficulty to ascribe precise boundaries to the $H$ layers and/or in the estimate of the ${ }^{230} \mathrm{Th}$ flux. Two distinct fluxes can be used, the vertical production rate of ${ }^{230} \mathrm{Th}_{\mathrm{xs}}$ (i.e., $\sim 9 \mathrm{dpm} \mathrm{cm}^{-2} \mathrm{kyr}^{-1}$ ) or the mean ${ }^{230} \mathrm{Th}_{\mathrm{xs}}$ flux of the glacial sequence (i.e., $\sim 15 \mathrm{dpm} \mathrm{cm}^{-2}$ $\left.\mathrm{kyr}^{-1}\right)$, resulting in maximum/minimum estimates for the duration of the $\mathrm{H}$ events. In the first case one assumes an almost complete collapse of the WBUC sedimentary supply during $\mathrm{H}$ events and therefore no ventilation of the deep water mass. The second case implies a reduced but steady WBUC supply during the whole glacial interval (H events included). We consider that a "higher supply hypothesis" can be discarded as it would imply, for example, higher smectite contents than observed.

The following minimum-maximum duration was obtained (also see Table 1): H0, 0.6 - $1.0 \mathrm{kyr} ; \mathrm{H1}, 0.8$ - $1.4 \mathrm{kyr} ; \mathrm{H} 2,0.8$ $1.3 \mathrm{kyr} ; \mathrm{H3}, 0.9-1.5 \mathrm{kyr}$; and H4, $1.3-2.1 \mathrm{kyr}$. The duration of $\mathrm{H} 4$ is questionable because the ${ }^{230} \mathrm{Th}_{\mathrm{xx}}$ calculation for the corresponding layer is not well constrained. Indeed, the large variations in the ${ }^{234} \mathrm{U} /{ }^{238} \mathrm{U}$ activity ratios within this layer raise doubts about any precise assessment of the "supported" ${ }^{230} \mathrm{Th}$ fraction. The other age estimates are better constrained. Although, the true maximum duration could be slightly lower than the above value, notably for $\mathrm{H} 0$, since the $K_{\text {arm }} / K$ profiles suggest probable mixing by bioturbation and thus some possible addition of ${ }^{230} \mathrm{Th}_{x s}$ on top of the layer from the overlaying hemipelagic clays. In Table 1 , values from the present study are compared with others from the literature based either on ${ }^{14} \mathrm{C}$ data and/or on ${ }^{230} \mathrm{Th}_{x s}$ calculations. We will limit our discussion to those based on radiometric methods, which should be directly comparable to this study. In most cases the estimates for any given event vary between authors by $100 \%$, depending on the time series studied and the method used, but remain within a range of $0.5-2 \mathrm{kyr}$ for all sets of events. Two main observations can be made. First, the depositional times based on observations or calculations as 
above are generally greater than those yielded by theoretical models [i.e. Alley and MacAyeal, 1994; Matsumoto, 1996]. Second, the maximum values from our study are close to ${ }^{14} \mathrm{C}$ derived estimates, thus suggesting that the ${ }^{230} \mathrm{Th}$ scavenging rate of $\sim 99 \mathrm{dpm} \mathrm{cm}^{-2} \mathrm{kyr}^{-1}$ (i.e., the vertical production) is a better estimate of the unsupported ${ }^{230} \mathrm{Th}$ flux during these

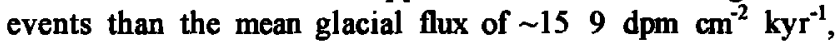
which represents the entire glacial sequence. This would imply a reduced WBUC supply (and thus a reduced outflow) during the $\mathrm{H}$ events compared with the glacial period as a whole. This interpretation would be in agreement with a change in the thermohaline circulation during $H$ events, notably a lesser production of North Atlantic Deep Water (which constitutes the core water mass of the WBUC in its gyre around the deep Labrador Sea basin) as suggested by trace element studies of benthic foraminifer shells [e.g., Boyle, 1995; Keigwin and Jones, 1995]. Our minimum estimates for $\mathrm{H} 1$ and $\mathrm{H} 2$ are in relative agreement with the maximum values reported by Francois and Bacon [1994]; we do not believe that this necessarily validates our values. The consistency between our maximum estimates and the ${ }^{14} \mathrm{C}$-based ages is also convincing, although the possible influence of ${ }^{14} \mathrm{C}$ plateau during these events, as for HO [Broecker, 1994], could raise doubts about the calculated ${ }^{14} \mathrm{C}$ duration. Differences in ${ }^{230} \mathrm{Th}_{\mathrm{xs}}$ estimates from site to site may be explained by difficulties in ascribing precise boundaries to Heinrich layers as well as by uncertainties inherent in the method itself, notably when defining unsupported ${ }^{230} \mathrm{Th}$ fluxes. Moreover, the apparent differences in depositional times could indeed represent true time differences from site to site, in relation to (1) distinct features (i.e. detrital carbonate versus IRD), (2) the dynamics of the iceberg dispersal, and/or (3) distinct supplies from major ice sheets other than LIS, i.e., from the Fennoscandian and Greenland ice sheets not necessarily in phase [Grousset et al., 1993; Fronval et al., 1995].

\section{Conclusion}

The sequence which has been used to constrain depositional times for $\mathrm{HO}, \mathrm{Hl}, \mathrm{H} 2, \mathrm{H} 3$, and $\mathrm{H} 4$ layers in the deep Labrador Sea has very specific features which strengthen some of the conclusions which can be made with respect to the duration of the corresponding depositional events using $U$ series data. First, it is located directly under the trajectory of the icebergs released by one of the most active margins of the Laurentidian Ice Sheet, i.e., the Hudson Strait area [Andrews et al., 1994] and is in an area that receives detrital carbonate pulses which were triggered from the same source area and channeled by the NAMOC [Andrews et al., 1995]. Second, the site is located below the high-velocity core of the WBUC and sheltered by Orphan Knoll (Figure 1). It thus lies out of the direct erosional influence of this current, but it is likely influenced by its distal sedimentary supplies [Fagel et al., 1996]. Therefore the $H$ layers of the studied core do represent the most exhaustive record for reconstructing the Laurentide ice dynamics along its NE margin. Furthermore, the ${ }^{230} \mathrm{Th}_{\mathrm{xg}}$ maximum duration for these events is well constrained since the unsupported ${ }^{230}$ Th flux used to calculate it corresponds to the vertical production rate of ${ }^{230} \mathrm{Th}$, i.e., to the minimum ${ }^{230} \mathrm{Th}$ flux conceivable (as sediment winnowing can be discarded here). This maximum duration apparently matches estimates based on ${ }^{14} \mathrm{C}$ chronologies elsewhere and thus constitutes the most probable value for the depositional time. As a consequence, the minimum duration, which was based on the assumption of stronger ${ }^{230} \mathrm{Th}$ fluxes induced by enhanced lateral supplies through WBUC transportation, seems invalid. If ascertained, this leads to the conclusion that the WBUC outflow was significantly reduced during $H$ events and that ${ }^{230} \mathrm{Th}$ export from the Labrador Sea by deep ventilation was similarly reduced.

Nevertheless, the maximum depositional times of $\sim 1.0 \pm 0.1$, $\sim 1.4 \pm 0.1, \sim 1.3 \pm 0.1, \sim 1.5 \pm 0.1$, and $\sim 2.1 \pm 0.1 \mathrm{kyr}$, which we obtained for $\mathrm{H}$ events $\mathrm{H} 0-\mathrm{H} 4$, respectively, are generally compatible with estimates based on other data when they exist. In this sequence the duration of $\mathrm{H} 4$ remains questionable because of the very peculiar U-Th systematics of this layer compared with the others. All other events yield a duration of 1-1.5 kyr. This suggests that the mechanisms involved in the deposition of these layers did not differ drastically from one to the other. This conclusion would be in favor of the glacier internal forcing mechanism for the $\mathrm{H}$ events invoked by several authors [e.g., Alley and MacAyeal, 1994; Fronval et al., 1995; Clarke et al., 1998).

\begin{abstract}
Acknowledgments. This study is part of a collaborative special project funded by the Natural Sciences and Engineering Research Council of Canada (NSERC). Its successful completion strongly benefited from the support of the following bodies and individuals to whom we express our sincere gratitude: Fisheries and Oceans Canada for providing ship time, the Atlantic Geoscience Center for providing the coring equipment and some logistical support, and the IsoTrace Laboratory of the University of Toronto for processing AMS ${ }^{14} \mathrm{C}$ measurements. Special thanks are also due to $S$. Vallières, who provided data on $U$ series measurements from low-resolution samples of core 9I045-094, to J. Stoner, who provided paleomagnetic data, and to S. Alpay, who kindly "edited" our English. We also acknowledge the help of G. Bilodeau, B. Ghaleb, L. Coumoyer, and M. Labelle for carrying analytical tasks. The final script benefited from reviews by J. Andrews, R. Francois, and one anonymous reviewer. Additional financial support was provided by PRAXIS XXI (student grant for CCVP) and by NSERC and FCAR awards to CHM.
\end{abstract}

\section{References}

Alley, R. B., and D. R. MacAyeal, Ice-rafted debris associated with binge/purge oscillations of the Laurentide Ice Sheet, Paleoceanography, 9, 503$511,1994$.

Ammenn, B., and A. F. Lotter, Late-glacia radiocarbon- and palynostratigrapby on the Swiss Plateau, Boreas, /8, 109-126, 1989.

Anderson, R. F., M. P. Bacon, and P. G. Brewer, Removal of ${ }^{330} \mathrm{Th}$ and ${ }^{231} \mathrm{~Pa}$ at ocean margins, Earth Planet. Sci. Lett., 66, 73-90, 1983.

Andrews, J. T., and K. Tedesco, Detrital carbonate- rich sediments, northwestern Labrador Sea: Implications for ice-sheet dynamics and iceberg rafting (Heinnch) events in the North Atlantic, Geology, 10, 1087-1090, 1992.

Andrews, J. T., H. Erlenkeuser, K. Tedesco, A. E. Aksu, and A. J. T. Jull, Late quaternary (stage 2 and 3) meltwater and Heinrich events, Northwest Labrador Sea, Quat. Res., 4I, 26-34, 1994.

Andrews, J. T., A. E. Jennings, M. Kerwin, M. Kirby, W. Manley, and G. H. Miller, A Heinrich-like event, HO (DC-0): Sounce(s) for detrital carbonate in the North Atlantic during the Younger Dryas chronozone, Paleoceanography, 10. 943-952, 1995.

Bard, E., Correction of AMS ${ }^{14} \mathrm{C}$ ages measured in planktonic foraminifera: Paleoceanographic implications, Paleoceanography, 3, 635-645, 1988.

Bilodeau, G., C. Hillaire-Marcel, A. de Vernal, and J. Stoner, Changes in the intermediate and deep Labrador Sea water masses during the last $25 \mathrm{ka}$ based on oxygen isotopes in planktic vs. benthic 
foraminifers, EOS. Trans. AGU,78(46), Fall Meet. Suppl., 1997.

Bonatti, E., D. E. Fisher, O. Joensuu, and H. S. Rydell, Postdepositional mobility of some transition elements, phosphorus, uranium and thorium in deep sea sediments, Geochim. Cosmochim. Acta, 35, 189-201, 1971.

Bond, G., and R. Lott1, Iceberg discharges into the North Atlantic on millennial time scales during the last glaciation, Science, 267, 1005-1010, 1995

Bond, G., et al., Evidence for massive discharges of icebergs into the North Atlantic Ocean during the last glacial perod, Nature, 360, 245-249, 1992.

Boyle, E , Last-Glacial-Maximum North Atlantic Deep Water: On, off or somewhere in-between?, Philos Trans. R. Soc London, Ser. B, 348, 243-253, 1995.

Broecker, W. S, Massive iceberg discharges as triggers for global climate change, Nature, 372 , 421-424, 1994.

Chen, J. H., R. Lawrence Edwards, and G. J. Wasserburg, ${ }^{238} \mathrm{U},{ }^{234} \mathrm{U}$ and ${ }^{232} \mathrm{Th}$ in seawater, Earth Planet. Sci. Lett., 80, 241-251, 1986

Chough, S. K., and R. Hesse, Submarine meandering talweg and turbidity currents flowing for 4,000 $\mathrm{km}$ in Northwest Atlantic Mid-Ocean Channel, Labrador Sea, Geology. 4, 529-533, 1976.

Clarke, G. K. C., S. J. Marshall, C. Hillaire-Marcel, G Bilodeau, and C. Veiga-Pires, A placiological perspective on Heinrich events, paper presented at Chapman Conference on Mechanisms of Millenial-Scale Global Climate Change, AGU, Snowbird, Utah, 1998.

Cochran, J. K., The Ocean Chemistry of the U- and Th-Series Nuclides, in Uranium series disequilibrium: applications to earth, marine. and envirommental sciences, edited by $\mathrm{M}$. Ivanovich and $R$. S. Harmon, pp. 423-455, Oxford Sci , 1982

Craig, H., Isotopic standards for carbon and oxygen and corrections factors, Geochim. Cosmochim. Acta, 12, 133-149, 1957

Dansgaard, W , H. B. Clausen, N. Gundestrup, C. U. Hammer, S. F. Johnsen, P. M. Kristinsdottir, and N. Reeh, A new Greenland deep ico core, Science, 218, 1273-1277, 1982

de Vernal, A., C. Hillaire-Marcel, and G. Bilodeau, Reduced meltwater outflow from the Laurentide ice margin during the Younger Dryas, Nature. 381, 774-777, 1996.

de Vernal, A., C. Hillaire-Marcel, J.L. Turon and J. Matthiessen, Sea-surface condition in the northern North Atlantic during the Last Glacial Maximum (LGM) The cold paradigm reviseted, Com. $J$ Earth Sci., in press, 1998.

Dowdeswell, J. A., M. A. Maslin, J. T. Andrews, and I. N. McCave, Iceberg production, debris rafting. and the extent and thickness of Heinrich layers (H-1, H-2) in North Atlantic sediments, Geology. 23, 301-304, 1995 .

Fagel, N., C. Robert, and C. Hillaire-Marel, Clay mineral signature of the NW Atlantic Boundary Undercurrent Mar. Geol, 130, 19-28, 1996.

Fagel, N., C. Hillaire-Marcel, and C. Robert, Changes in the Western Boundary Undercurrent outflow since the Last Glacial Maximum, from smectite/illite ratios in deep Labrador Seg sediments, Paleoceanography, 12, 79-96, 1997.

François, R., and M. P. Bacon, Heinrich events in the North Atlantic: Radiochemical evidence, Deep Sea Res. Part I, 41, 315-334, 1994.

Fronval, T., E. Jansen, J. Bloemendal, and $S$. Johnsen, Oceanic evidence for coherent fluctuations in Fennoscandian and Laurentide ice sheets on millennium timescales, Nature, 374, 443-446, 1995.

Gariépy, C, B. Ghaleb, C. Hillaire-Marcel, A. Mucci, and $S$. Vallieres, Early diagenetic processes in Labrador Sea sediments: Uranium-isotope geochemistry, Can. J. Earth Sci., 31, 28-37, 1994.

Grousset, F. E., L. Labeyrie, J. A. Sinko, M. Cremer,
G. Bond, J. Duprat, E. Cortijo, and S Huon, Patterns of ice-rafted detritus in the glacial North Atlantic $\left(40^{\circ}-55^{\circ} \mathrm{N}\right)$, Paleoceanography, 8,175 192, 1993

Heinrich, $\mathrm{H}$, Origin and consequences of cyclic ice rafting in the northeast Allantic Ocean during the past 130,000 Years, Quat. Res., 29, 142-152, 1988.

Hesse, R., I. Klaucke, W. B. F. Ryan, and D J. W. Piper, Ice-sheet source juxtaposed turbidite systems in Labrador Sea, Geosci. Can., 24, 3-12, 1997.

Hillaire-Marcel, C., A. De Vernal, G. Bilodeau, and G. Wu, Isotope stratigraphy, sedimentation rates, deep circulation, and carbonate events in the Labrador Sea during the last $\sim 200 \mathrm{Ka}$, Can. $J$. Earth Sci., 31, 63-89, 1994a.

Hillaire-Marcel, C., A. De Vernal, M. Lucotte, A Mucei, G. Bilodeau, A. Rochon, $\mathbf{S}$. Vallières, and G. Wu, Productivité et flux de carbone dans la mer du Labrador au cours des derniers 40000 ans, Can. J Earhh Sci., 31, 139-158, 1994b.

Hillaire-Marcel, C., D. Assameur, G. Bilodeau, A. de Vernal, J. Stoner, S. Vallières, and C. Veiga-Pires, Fast deposited units (cf. Heinrich layers) in the Last Glacial Labrador Sea, paper presented at International Congress of Paleoceanography $\mathrm{V}$, xx, Halifax, N.S., Can., 1995.

Honeyman, B. D., and P. H. Santschi, The role of particles and colloids in the transport of radionuclides and trace metals in oceans, Envirom. Part., 1, 380-423, 1992.

Jannasch, H. W., B. D. Honeyman, L. S. Balistrieri, and J. W. Murray, Kinetics of trace element uptake by marine particles, Geochim Cosmochim. Acla, 52, 567-577, 1988

Keigwin, L. D., and G A. Jones, The marine record of deglaciation from the continental margin off Nova Scotia, Paleoceanography, 10, 973-985, 1995

Kitagawa, H., and J. van der Plicht, Atmospheric radiocarbon calibration to 45,000 yr B.P.: Lato glacial fluctuations and cosmogenic isotope production, Science, 279, 1187-1190, 1998.

ally, A. E., Chemical procedures, in Uranium series Disequilibrium: Applications to Earth, Marine and Envirommental Sciences, edited by $M$. lvanovitvh and R. S. Harmon, pp. 95-126, Clarendon, Oxford, Eng., U.K., 1992.

Lao, Y., R. F. Anderson, W. S. Broecker, H. J. Hofmann, and $W$. Wolfli, Particulate fluxes of ${ }^{230} \mathrm{Th},{ }^{231} \mathrm{~Pa}$, and ${ }^{10} \mathrm{Be}$ in the northeastern Pacific Ocean, Geochim. Cosmochim. Acta, 57, 205-217, 1993

Lehman, S. J., G. A. Jones, L. D. Keigwin, E. S Andersen, G. Butenko, and S. R. Ostmo, Initiation of Fennoscandian ice-sheet retreat during the last deglaciation, Nature, 349, 513 516,1991 .

Manighetti, B., I. N. MeCave, M. Maslin, and N. J. Shackleton, Chronology for climate change: Developing age models for the Biogeochemical Ocean Flux Study cores, Paleoceanography, 10 , 513-525, 1995.

Martinson, D. G., N. G. Pisias, J. D. Hays, J. Imbrie, T. C. Moore Jr., and N. J. Shackleton, Age dating and the orbital theory of the ice ages: Development of a high-resolution 0 to 300,000 year chronostratigraphy, Qwat. Res., 27, 1-29, 1987.

Matsumoto, K., An iceberg drift and decay model to compute the ice-rafted debris and iceberg meltwater flux: Application to the interglacial North At]antic, Paleoceanography, 11, 729-742, 1996.

MoCartney, M. S., Recirculating components to deep boundary current of the North Atlantic, Prog. Oceanogr, 29, 283-383, 1992.

Moran, S. B., and R.M. Moore, Kinetics of the removal of dissolved aluminum by diatoms in seawater: A comparison with thorium, Geochum Cosmochim. Acta, 56, 3365-3374, 1992.

Moran, S. B., M. A. Charette, J. A. Hoff, R. L.
Edwards, and W. M. Landing, Distribution of ${ }^{230} \mathrm{Th}$ in the Labrador Sea and its relation to ventilation, Earth Plonet. Sci. Lett., J50, 151160, 1997.

Niven, S. E. H., P. E Kepkay, and A. Boraie, Colloidal organic carbon and colloidal ${ }^{234} \mathrm{Th}$ dynamics during a coastal phytoplankton bloom. Deep Sea Res. Part II, 42, 257-273, 1995.

Piper, D. J. W., Glaciomarine sedimentation on the continental slope off eastern Canada, Geosci Can., 15, 23-38, 1988.

Scholten, J. C., R. Botz, A Mangini, H. Paetsch, P Stoffers, and E. Vogeisang, High resolution ${ }^{230} \mathrm{Th}_{\text {ex }}$ stratigraphy of sediments from highlatitude areas (Norwegian Sea, Fram Strait), Earth Planet. Sci. Lett., 101, 54-62, 1990.

Stoner, J. S., J. E T. Channell, and C. HillaireMarcel, The magnetic signature of rapidly deposited detrital layers from the deep Labrado Sea. Relationshup to North Atlantic Heinrich layers, Paleoceanography, $l 1,309-325,1996$

Stoner, J. S., J. E. T Channell, and C. HillaireMarcel A 200 kyr geomagnetic chronostratigraphy for the Labrador Sea: Indirect correlation of the sediment record to SPECMAP Earth Planet. Set Lett , 159,155-181, 1998.

Stuiver, M., and P.J. Reimer, Extended ${ }^{14} \mathrm{C}$ data base and revised CALIB $30{ }^{14} \mathrm{C}$ age calibration program, Radiocarbon, 35, 215-230, 1993

Suman, D $O$, and M. P. Bacon, Variations in Holocene sedimentation in the North American Basin determined from ${ }^{230} \mathrm{Th}$ measurements, Deep Sea Res. Part A, 36, 869-878, 1989.

Thomson, J., N. C. Higgs, and T. Clayton, A geochemical criternon for the recognition of Heinnch events and estimation of their depositional fluxes by the ${ }^{230} \mathrm{Th}_{\text {exoess }}$ profiling method, Earth Planet. Sct Lett., I35, 41-56, 1995 .

Thomson, J., I. Jarvis, D. R H. Green, D. A. Green, and T. Clayton, Mobility and immobility of redox sensitive elements in deep-sea turbidites during shallow burial, Geochim Cosmochim. Acta, 62, 643-656, 1998.

Vallières, S., Flux d'uranium et excès de ${ }^{230} \mathrm{Th}$ dans les sédiments de la mer du Labrador - Relation avec les conditions paléocéanographiques et la productivité du bassin, $\mathrm{Ph} D$. thesis, Univ. du Québec à Montréal, 140 pp., Montréal, Qué. Can., 1997.

Vallières, S., C. Hillaire-Marcel and B. Ghaleb, Déséquilibres U-Th dans les dépôts meubles des basses-terres du Saint-Laurent, Québec, Can. $J$ Earth Sci., 30, 1730-1740, 1993.

Veiga-Pires, C., Flux de Thonum-230 et flux sédimentaires dans l'Atlantique du Nord Ouest au cours des demiers $40 \mathrm{ka}$ en relation avec les variations du climat Ph.D thesis, Univ du Québec à Montréal, 169 pp., Montréal, Qué. Can., 1998.

Vidal, L., L. Labeyrie, E. Cortijo, M. Arnold, J. C Duplessy, E. Michel, S. Becqué, and T. C E. van Weering, Evidence for changes in the North Atlantic Deep Water linked to meltwater surges during the Heinrich events, Earth Planet. Sct. Lett., 146, 13-27, 1997

Yu, E., R. Francois, and M. P. Bacon, Similar rates of modern and last-glacial ocean thermohaline circulation inferred from radiochemical data Nature, 379, 689-694, 1996

C. Hillaire-Marcel, Centre de Recherche en Geochimie et en Géochronologie Isotopique (GEOTOP), Université du Québec à Montréal, P.O. Box 8888, Suc. Centre Ville, Montréal, Québec, Canada H3C 3P8.

C.C. Veiga-Pires, Universidade do Algarve, 8000 Faro, Portugal. (cvpires@ualg.pt.edu)

(Received January 9, 1998 revised September 25, 1998 accepted October 1, 1998.) 